\title{
Genetic Polymorphisms of HBS1L-MYB (rs4895441 and rs9376090) in Egyptian Patients with Hemoglobinopathy
}

\author{
Thoria A. Omar'1, Emad F. Abd-Elhalim¹, Rawhia H. Eledel'1, Mohamed A. Soliman', \\ Fatma S. Ebeid ${ }^{2}$, Ola H. Elshafey ${ }^{1}$, Dalia H. Abou-Elela ${ }^{1}$
}

${ }^{1}$ Clinical Pathology Department, Faculty of Medicine, Menoufia University, Shibin El Kom, Egypt

${ }^{2}$ Pediatric Department, Faculty of Medicine, Ain Shams University, Ain Shams, Egypt

Email: olla_elshafey@yahoo.com

How to cite this paper: Omar, T.A., Abd-Elhalim, E.F., Eledel, R.H., Soliman, M.A., Ebeid, F.S., Elshafey, O.H. and Abou-Elela, D.H. (2020) Genetic Polymorphisms of HBS1L-MYB (rs4895441 and rs9376090) in Egyptian Patients with Hemoglobinopathy. Open Journal of Blood Diseases, 10 , 89-100.

https://doi.org/10.4236/ojbd.2020.104011

Received: September 19, 2020

Accepted: November 28, 2020

Published: December 1, 2020

Copyright $\odot 2020$ by author(s) and Scientific Research Publishing Inc. This work is licensed under the Creative Commons Attribution International License (CC BY 4.0).

http://creativecommons.org/licenses/by/4.0/

\begin{abstract}
Objective: Study the HBS1L-MYB (rs4895441 and rs9376090) genetic polymorphisms in Egyptian patients with $\beta$-thalassemia major and sickle cell disease and its relation to $\mathrm{Hb} \mathrm{F}$ and severity of the disease. Background: $\mathrm{Hb} \mathrm{F}$ is a predominant modulator for the severity of $\beta$-thalassemia major $\&$ sickle cell disease. Genetic polymorphism in the intergenic region (HBS1L-MYB) between GTP-binding elongation factor HBS1L and myeloblastosis oncogene MYB on chromosome $6 \mathrm{q}$ is associated with high fetal hemoglobin levels. Subjects and Methods: 150 subjects were included in this study. For all studied groups: Complete blood picture and serum ferritin were evaluated. For patients, hemoglobin variants were separated by High-performance liquid chromatography. Genotyping of HBS1L-MYB (rs4895441 \& rs9376090) was evaluated by real-time polymerase chain reaction technique using TaqMan probe. Results: AG, CT genotypes, and G, C alleles of HBS1L-MYB (rs4895441 \& rs9376090) were significantly high in sickle cell patients [OR (3.400); 95\% C.I (1.482 - 7.799)], $(\mathrm{p}=0.003)$ \& [OR (4.522); 95\% C.I (1.854 $11.029)],(p=0.001)$ respectively. Also, a significant association was detected between polymorphisms and disease severity. However, in $\beta$-thalassemia major, no significant association was detected. Conclusion: In sickle cell disease patients, Genetic polymorphisms in HBS1L-MYB (rs9376090 \& rs4895441) affect the level of $\mathrm{Hb} \mathrm{F}$ which could improve the prognosis of these patients.
\end{abstract}

\section{Keywords}

Hemoglobinopathy, Beta-Thalassemia, Sickle Cell Disease, HBS1L-MYB Polymorphism, Polymerase Chain Reaction 


\section{Introduction}

Hemoglobinopathies are inherited diseases caused by defects in globin chain synthesis; they include thalassemia syndromes, sickle cell disease \& globin chain variants [1]. $\beta$-thalassemia results from numerous mutations or rarely deletions of the $\beta$ globin gene on chromosome 11 . These mutations primarily point mutations that affect transcriptional control, translation, and splicing of the $\mathrm{Hb} \mathrm{B}$ gene and gene product [2].

$\beta$-thalassemia is characterized by chronic anemia and iron excess due to blood transfusion and increased gastrointestinal absorption [3]. A comparison of Egyptian $\beta$-thalassemia patients with their healthy peers revealed that the former reported lower growth parameters, lower physical, mental, schoolwork, and overall quality of life scores [4].

The intensity of $\beta$-thalassemia may be mitigated by the production of $\mathrm{Hb} \mathrm{F}$ as it may alter the imbalance of the $\alpha / \beta$ globin chain [5].

Sickle cell disease $(S C D)$ is considered as one of the commonest gene disorders of human beings. In Africa, more than 200,000 infants are born yearly with sickle cell anemia [6]. Sickle cell disease is an inherited genetic disorder, resulting from homozygous and compound heterozygote mutation in the $\beta$ globin gene as a single base-pair point mutation (GAG to GTG) results in the substitution of glutamic acid (hydrophilic) to Valine (hydrophobic) in the $6^{\text {th }}$ position of the $\beta$-chain of hemoglobin resulting in hemoglobin $\mathrm{S}$ formation [7].

The increase of $\mathrm{Hb} \mathrm{F}$ can decrease the severity of SCD because of its ability to inhibit the polymerization of $\mathrm{Hb} \mathrm{S}[8]$.

$\mathrm{Hb} \mathrm{F}$ expression is affected by several quantitative trait loci (QTL) within and outside the $\beta$ globin gene cluster. The HBG2, BCL11A \& HBS1L-MYB are well-known major modifier loci [9]. HBS1L-MYB genes are expressed in the precursor cells of the erythroid. HBS1L encodes a protein with apparent GTP binding activity and is included in different cellular processes while MYB encodes a transcription factor for erythroid differentiation in hematopoiesis [10]. Disturbance in the interval between the HBS1L and MYB suppresses MYB expression and gives rise to the increased level of $\mathrm{Hb} \mathrm{F}$ [7]. Single nucleotide polymorphisms (SNPs) in the G $\gamma$-globin gene promoter in BCL11A regions and HBS1L-MYB intergenic polymorphism (HMIP) are thought to be associated with $\mathrm{Hb} \mathrm{F}$ levels. Strongly associated markers in HMIP block 2, are either in intron 1a (rs9376090, rs9399137, rs9402685 and rs11759553), or directly upstream of the 5 UTR of HBS1L exon 1a (rs4895440, rs4895441, rs9376092, rs9389269, rs9402686, rs11154792 and rs9483788) [11].

With the increasing prevalence of $\beta$-thalassemia and SCD among Egyptian children, regardless of traditional genetic factors, there are no data related to the association of HBS1L-MYB intergenic polymorphism with these conditions. Thus, this study was done to investigate the association of HBS1L-MYB (rs 9376090 \& rs 4895441) genetic polymorphisms in Egyptian patients with $\beta$-thalassemia major \& sickle cell disease and its relation to $\mathrm{Hb} \mathrm{F}$ and disease 
severity.

\section{Subjects and Methods}

This case-control study was conducted in the Clinical Pathology Department, Menoufia University and, Pediatric Department, Ain-shams University from September 2018 to December 2019. One hundred fifty subjects were included and divided into three groups:

Group [1] ( $\beta$-thalassemia major patients): included 50 patients with $\beta$-thalassemia major diagnosed by HPLC and under regular blood transfusion.

Group [2] (sickle cell patients): included 50 sickle cell disease patients, diagnosed by HPLC and under hydroxyurea therapy.

Group [3] (controls): included 50 apparently healthy subjects, age and gender-matched with patients.

Informed written consent was attained from subjects who participated in this study. The study was approved by the Ethical Committee of Medical Research, Faculty of Medicine, Menoufia University.

For all subjects: Complete history taking, complete blood count, serum ferritin and genotyping of HBS1L-MYB (rs4895441 \& rs9376090) by real-time polymerase chain reaction technique were done. Also, separation of hemoglobin variants by high-performance liquid chromatography (HPLC) for patients.

Samples collection: Before the planned blood transfusion (for $\beta$-thalassemia major patients) and under complete aseptic conditions, $5 \mathrm{ml}$ of venous blood were collected, and then divided as follows: $2 \mathrm{ml}$ were collected into an EDTA tube for CBC and HPLC, another EDTA tube with $2 \mathrm{ml}$ blood for genotyping of HBS1L-MYB gene. The remaining $1 \mathrm{ml}$ was collected in a plain tube for measurement of serum ferritin level.

Laboratory investigations: Serum ferritin was done by the auto-analyzer (HITACHI Cobas e 411 High-Technologies Corporation Tokyo, Japan). Complete blood count was done by Sysmex1 XN-1000 Automated Hematology Analyzer (Sysmex Corporation, Japan). Hb separation and quantification was carried out using HPLC “Arkray, ADAMS" A1c HA8180T analyzer" (Kyoto, Japan) and Bio-Rad D10-Hemoglobin A1C Testing system (Bio-Rad Laboratories, Hercules, CA, USA).

\section{Determination of HBS1L-MYB (rs 9376090 and rs 4895441) Genotypes by Real Time-PCR}

1) Genomic DNA extraction: [12]

The genomic double-stranded DNAs were extracted from whole blood using (Thermo Scientific Gene Jet. Whole Blood Genomic DNA Purification Mini Kit) supplied by (Thermo Fisher Scientific, USA). The purity and concentration of extracted DNAs were observed with a spectrophotometer (Implen NanoPhotometer ${ }^{\mathrm{TM}}$ N60 UV/VIS spectrophotometer, Germany). The eluted genomic DNA was aliquoted and stored at $-80^{\circ} \mathrm{C}$ until the performance of PCR. 
2) TaqMan SNP genotyping assay: [13]

Genotyping of HBS1L-MYB (rs 9376090 and rs 4895441) polymorphism was performed using ABI 7500 real-time PCR system (Applied Biosystem, Foster City, California, USA). Fluorescent labeled probes, TaqMan probes (Thermo Fisher Scientific, USA) [VIC/FAM]:

(rs4895441):

CTGGGGAGAAAGACTCTTTGTAAAGT[A/G]TACATGAGCAGAACTGAG

TAAGT.

(rs9376090):

AGCTAAGTCTAGCTGAGTGTTAG[C/T]GGGGGATACTGCCAGGAACAA ATGA.

PCR reaction was done by adding $30 \mu$ Master mix (Applied Biosystems, Foster City, CA), $3.75 \mu$ primer, extracted DNA (according to measured DNA concentration), and $11.25 \mu$ sterile deionized water into PCR wells, PCR was done by the following conditions: initial denaturation at $94^{\circ} \mathrm{C}$ for 5 minutes, 40 cycles $\left(94^{\circ} \mathrm{C}\right.$ for $30 \mathrm{sec}$ for denaturation then $62^{\circ} \mathrm{C}$ for 1 minute for annealing) and for final extension 7 minutes at $72^{\circ} \mathrm{C}$ min.

\section{Statistical Analysis}

Results were collected, tabulated, and statistically analyzed by an International Business Machines (IBM) compatible personal computer with Statistical Package for the Social Sciences (SPSS) version 23 (SPSS Inc. Released 2015.IBM SPSS statistics for windows, version 23. 0, Armnok, NY: IBM Corp.) Data were expressed as mean $(\bar{x})$, standard deviation (SD), Number (No), and percentage (\%). Kruskal Wallis, Chi-square, Mann Whitney, Fischer's Exact, Post hoc tests were used. Two-sided P-value of $\leq 0.05$ was considered statistically significant.

\section{Results}

In $\beta$-thalassemia major patients, age of disease presentation was ranged from (6 11 months). Thirty-seven $\beta$-thalassemia major patients were on regular blood transfusion every 3 weeks, while thirteen of them were on regular blood transfusion every 5 weeks. In SCD, the age of disease presentation was (9 - 36 months) and the numbers of crises were ( 1 - 8/year). There was a statistically significant increase in serum ferritin in $\beta$-thalassemia than controls, also a significant decrease in $\mathrm{Hb}$ level in $\beta$-thalassemia compared to other groups (Table 1). HPLC for $\mathrm{Hb}$ distribution in $\beta$-thalassemia major and sickle cell disease patients showed a significant difference between the two groups regarding $\mathrm{Hb} \mathrm{A}$ and $\mathrm{Hb}$ F (Table 2).

The independent segregation genotype for the two SNPs in the controls was in agreement with the Hardy-Weinberg equilibrium $(p>0.05)$ as (AA) and (TT) were the wild types of HBS1L-MYB (rs4895441 and rs9376090) respectively. AG, CT genotypes and, G, C alleles of HBS1L-MYB (rs4895441 and rs9376090) polymorphisms, were significantly higher in sickle cell disease patients. Also sig- 
nificant difference was detected between sickle cell disease and thalassemia patients regarding (rs9376090) with no significant difference regarding (rs4895441) (Table 3(a)). In $\beta$-thalassemia major, no significant difference was detected between $\beta$-thalassemia major patients and controls regarding HBS1L-MYB (rs4895441 \& rs9376090) genotyping and allele's frequency (Table 3(b)).

While in SCD, (Table 3(c)) comparing CT, AG, genotypes of rs9376090 \& rs4895441 between SCD and control; CT and AG were significant in SCD (P = 0.001), [OR (4.522); 95\% C.I (1.854 - 11.029)] \& (P 0.003), [OR (3.400) \& 95\% C.I (1.482 - 7.799)] respectively. Also $C$ and $G$ alleles frequency of both genes were significantly high in SCD ( $\mathrm{P}=0.001)$ [OR (3.500); 95\% C.I (1.595 - 7.679)] $\&$ (P 0.030) [OR (2.092); 95\% C.I (1.066 - 4.108)] respectively.

Table 1. Comparison between the studied groups according to demographic and laboratory data.

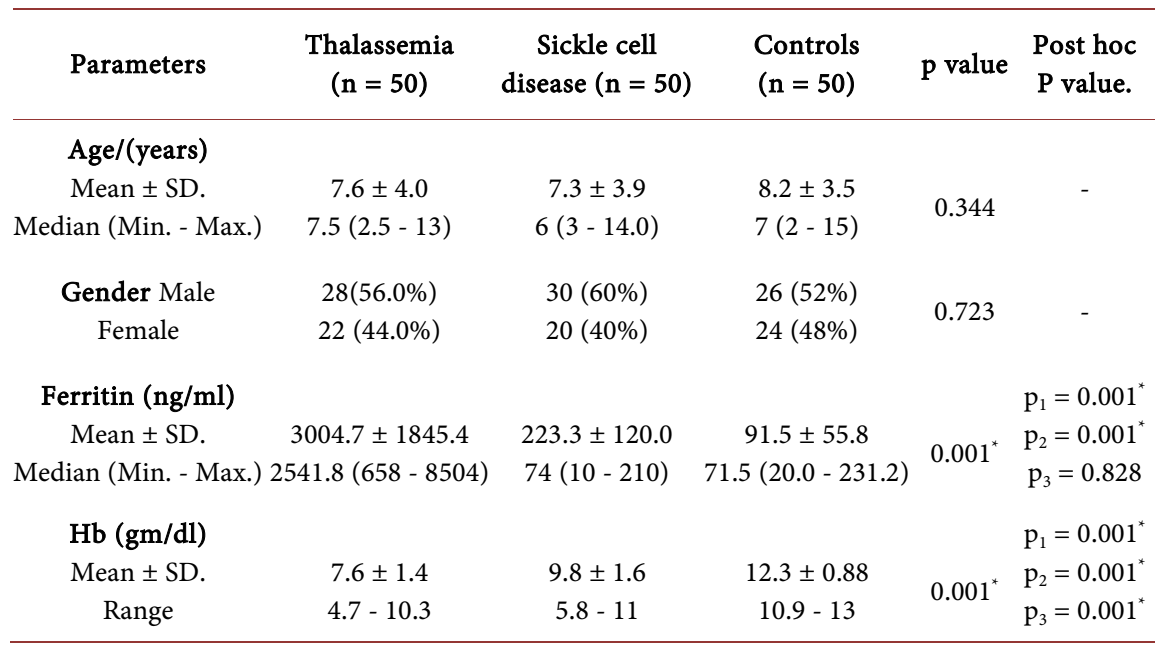

SD: standard deviation, $\mathrm{p}$ : p-value for comparing between the studied groups. ${ }^{*}$ : Statistically significant at $\mathrm{p}$ $\leq$ 0.05. p1: $\mathrm{p}$-value for comparing Thalassemia and Sickle cell disease. $\mathrm{p}_{2}: \mathrm{p}$-value for comparing Thalassemia and controls. $\mathrm{p}_{3}$ : $\mathrm{p}$-value for comparing Sickle cell disease and controls.

Table 2. Comparison between Thalassemia and Sickle cell groups according to HPLC results.

\begin{tabular}{cccc}
\hline Parameters & $\begin{array}{c}\text { Thalassemia } \\
(\mathbf{n}=50)\end{array}$ & $\begin{array}{c}\text { Sickle cell disease } \\
(\mathbf{n}=50)\end{array}$ & P value \\
HB F\% & $16.8 \pm 14.4$ & $8.0 \pm 5.9$ & $<0.001^{*}$ \\
Mean \pm SD & & & 0.060 \\
HB A2\% & $3.3 \pm 0.95$ & $2.9 \pm 1.2$ & \\
Mean \pm SD & & & \\
HB A\% & $80.2 \pm 14.5$ & $30 \pm 12.4$ & \\
Mean \pm SD & & & - \\
HB S\% & & $59.5 \pm 21.6$ & \\
Mean \pm SD & &
\end{tabular}

SD: standard deviation, $\mathrm{p}$ : $\mathrm{p}$-value for comparing between the studied groups. ${ }^{\star}$ : Statistically significant at $\mathrm{p}$ $\leq 0.05$. 
Table 3. (a): Distribution of HBS1L-MYB (rs9376090 and rs4895441) genotypes and allele frequency among the studied groups; (b): Comparison between Thalassemia and control groups regarding HBS1L-MYB (rs9376090 and rs4895441) genotypes and allele frequency; (c): Comparison between Sickle cell disease and control regarding HBS1L-MYB (rs9376090 and rs4895441) genotypes and allele frequency.

(a)

\begin{tabular}{ccccc}
\hline Parameters & $\begin{array}{c}\text { Thalassemia } \\
(\mathbf{n}=\mathbf{5 0})\end{array}$ & $\begin{array}{c}\text { Sickle cell disease } \\
(\mathbf{n}=50)\end{array}$ & $\begin{array}{c}\text { Controls } \\
(\mathbf{n}=50)\end{array}$ & P value \\
\hline rs9376090 & & & & \\
TT & $41(82 \%)$ & $23(46 \%)$ & $40(80 \%)$ & $\mathrm{p}_{1}=0.001^{*}$ \\
CT & $6(12 \%)$ & $26(52 \%)$ & $10(20 \%)$ & $\mathrm{p}_{2}=0.13$ \\
CC & $3(6 \%)$ & $1(2 \%)$ & $0(0 \%)$ & $\mathrm{p}_{3}=0.001^{*}$ \\
Allele frequency & & & & $\mathrm{p}_{1}=0.004^{*}$ \\
T & $88(88 \%)$ & $72(72 \%)$ & $90(90 \%)$ & $\mathrm{p}_{2}=0.65$ \\
C & $12(12 \%)$ & $28(28 \%)$ & $10(10 \%)$ & $\mathrm{p}_{3}=0.001^{*}$ \\
rs4895441 & & & \\
AA & $28(56 \%)$ & $20(40 \%)$ & $34(68 \%)$ & $\mathrm{p}_{1}=0.06$ \\
AG & $20(40 \%)$ & $30(60 \%)$ & $15(30 \%)$ & $\mathrm{p}_{2}=0.44$ \\
GG & $2(4 \%)$ & $0(0 \%)$ & $1(2 \%)$ & $\mathrm{p}_{3}=0.008^{*}$ \\
Allele frequency & & & & $\mathrm{p}_{1}=0.33$ \\
A & $76(76 \%)$ & $70(70 \%)$ & $83(83 \%)$ & $\mathrm{p}_{2}=0.22$ \\
G & $24(24 \%)$ & $30(30 \%)$ & $17(17 \%)$ & $\mathrm{p}_{3}=0.03^{*}$ \\
\hline
\end{tabular}

P: $p$ value for comparing between the studied groups. $\mathrm{p}_{1}$ : $\mathrm{p}$-value for comparing between Thalassemia and Sickle cell disease. $\mathrm{p}_{2}: \mathrm{p}$-value for comparing between Thalassemia and controls. $\mathrm{p}_{3}: \mathrm{p}$-value for comparing between Sickle cell disease and controls. *: Statistically significant at $\mathrm{p} \leq 0.05$.

(b)

\begin{tabular}{|c|c|c|c|c|}
\hline Parameters & $\begin{array}{l}\text { Thalassemia } \\
\quad(n=50)\end{array}$ & $\begin{array}{c}\text { Controls } \\
(n=50)\end{array}$ & $\mathrm{p}$ & OR (95\% C.I) \\
\hline \multicolumn{5}{|l|}{ rs9376090 } \\
\hline $\mathrm{TT}^{\infty}$ & $41(82 \%)$ & $40(80 \%)$ & - & 1.000 \\
\hline $\mathrm{CT}$ & $6(12 \%)$ & $10(20 \%)$ & 0.337 & $0.585(0.194-1.762)$ \\
\hline $\mathrm{CC}$ & $3(6 \%)$ & $0(0 \%)$ & 0.243 & - \\
\hline \multicolumn{5}{|l|}{ Allele frequency } \\
\hline $\mathrm{T}^{\infty}$ & $88(88 \%)$ & $90(90 \%)$ & --- & 1.000 \\
\hline $\mathrm{C}$ & $12(12 \%)$ & $10(10 \%)$ & 0.651 & $1.227(0.504-2.986)$ \\
\hline \multicolumn{5}{|l|}{ rs4895441 } \\
\hline $\mathrm{AA}^{\infty}$ & $28(56 \%)$ & $34(68 \%)$ & - & 1.000 \\
\hline AG & $20(40 \%)$ & $15(30 \%)$ & 0.257 & $1.619(0.702-3.734)$ \\
\hline GG & $2(4 \%)$ & $1(2 \%)$ & 0.591 & $2.429(0.209-28.200)$ \\
\hline \multicolumn{5}{|c|}{ Allele frequency } \\
\hline $\mathrm{A}^{\infty}$ & $76(76 \%)$ & $83(83 \%)$ & --- & 1.000 \\
\hline G & $24(24 \%)$ & $17(17 \%)$ & 0.220 & $1.542(0.770-3.089)$ \\
\hline
\end{tabular}

OR: Odds ratio, ${ }^{\bullet}$ : Reference type, CI: Confidence interval, LL: Lower limit, UL: Upper Limit, p: p-value for comparing between the studied group, *: Statistically significant at $\mathrm{p} \leq 0.05$. 
(c)

\begin{tabular}{|c|c|c|c|c|}
\hline Parameters & $\begin{array}{l}\text { Sickle cell disease } \\
\qquad(\mathrm{n}=50)\end{array}$ & $\begin{array}{l}\text { Controls } \\
(n=50)\end{array}$ & $\mathrm{p}$ & OR (95\% C.I) \\
\hline \multicolumn{5}{|l|}{ rs9376090 } \\
\hline $\mathrm{TT}^{\circ}$ & $23(46 \%)$ & $40(80 \%)$ & - & 1.000 \\
\hline $\mathrm{CT}$ & $26(52 \%)$ & $10(20 \%)$ & $<0.001^{*}$ & $4.522(1.854-11.029)$ \\
\hline $\mathrm{CC}$ & $1(2 \%)$ & $0(0 \%)$ & 0.375 & - \\
\hline \multicolumn{5}{|c|}{ Allele frequency } \\
\hline $\mathrm{T}^{\circ}$ & $72(72 \%)$ & $9(90 \%)$ & $<0001^{*}$ & 1.000 \\
\hline $\mathrm{C}$ & $28(28 \%)$ & $10(10 \%)$ & & $3.500(1.595-7.679)$ \\
\hline \multicolumn{5}{|l|}{ rs4895441 } \\
\hline $\mathrm{AA}^{\circ}$ & $20(40 \%)$ & $34(68 \%)$ & - & 1.000 \\
\hline AG & $30(60 \%)$ & $15(30 \%)$ & $0.003^{*}$ & $3.400(1.482-7.799)$ \\
\hline GG & $0(0 \%)$ & $1(2 \%)$ & 1.000 & - \\
\hline \multicolumn{5}{|c|}{ Allele frequency } \\
\hline $\mathrm{A}^{\circ}$ & $70(70 \%)$ & $83(83 \%)$ & ---- & 1.00 \\
\hline G & $30(30 \%)$ & $17(17 \%)$ & $0.030^{*}$ & $2.092(1.066-4.108)$ \\
\hline
\end{tabular}

OR: Odds ratio, ${ }^{\bullet}$ Reference type, CI: Confidence interval, LL: Lower limit, UL: Upper Limit, p: p-value for comparing between the studied group, ${ }^{*}$ : Statistically significant at $\mathrm{p} \leq 0.05$.

In $\beta$-thalassemia major patients, there was no significant association between HBS1L-MYB (rs 9376090 and rs 4895441) genotypes and age of disease presentation, frequency of blood transfusion, splenectomy, Hb level, and $\mathrm{Hb} F$ (Table 4). Meanwhile, in the SCD group, CT genotype of HBS1L-MYB (rs 9376090) was significantly associated with a lower number of crises and lower $\mathrm{Hb} \mathrm{S}$ level, however, no significant association was detected between this polymorphism and age of disease presentation and $\mathrm{Hb}$ F, while AG genotype of HBS1L-MYB (rs4895441) was significantly associated with lower number of sickling crises, higher age of disease presentation, higher $\mathrm{Hb} \mathrm{F}$ and lower $\mathrm{Hb} \mathrm{S}$ levels (Table 5).

\section{Discussion}

$\beta$-thalassemia and SCD are serious autosomal hereditary disorders that occur in several populations around the world. $\beta$-thalassemia is associated with genetic mutations that contribute to a reduced or total loss of expression of the $\beta$-globin gene. While in the SCD, mutation of the $\beta$-globin gene induces alterations in protein structure [14]. In $\beta$-thalassemia, the accumulation of unbound alpha-globin chains precipitates in the erythrocyte precursors resulting in bone marrow destruction resulting in ineffective erythropoiesis. As well, excess unbound alpha-globin chains cause membrane damage in mature red thalassemia cells leading to hemolysis [15]. SCD pathogenesis starts when hemoglobin deoxy-sickle molecules are polymerized leading to the deformation of the red blood cell structure. Due to environmental and genetic factors, clinical phenotypes are extremely variable in both diseases, ranging from relatively mild to severe anemia [14]. 
Table 4. Relation of HBS1L-MYB (rs9376090 \& rs 4895441) genotypes with clinical and laboratory features of thalassemia patients.

\begin{tabular}{|c|c|c|c|c|c|c|c|}
\hline \multirow{2}{*}{ Parameters } & \multirow{2}{*}{$\begin{array}{c}\text { Age of } \\
\text { presentation } \\
\text { "months" } \\
\text { mean } \pm \mathrm{SD}\end{array}$} & \multicolumn{2}{|c|}{$\begin{array}{l}\text { Frequency of blood } \\
\text { transfusion }\end{array}$} & \multicolumn{2}{|c|}{ Splenectomy } & \multirow{2}{*}{$\begin{array}{c}\mathrm{Hb} \\
\text { mean } \pm \mathrm{SD}\end{array}$} & \multirow{2}{*}{$\begin{array}{c}\mathrm{Hb} F \% \\
\text { mean } \pm \mathrm{SD}\end{array}$} \\
\hline & & $\begin{array}{c}\text { Regular } \\
\text { (every } 3 \\
\text { w) }\end{array}$ & $\begin{array}{c}\text { Regular } \\
\text { (every } 5 \\
\text { w) }\end{array}$ & Yes & No & & \\
\hline \multicolumn{8}{|c|}{ rs 9376090} \\
\hline TT & $6.6 \pm 1.4$ & $34(82.8 \%)$ & $7(7.2 \%)$ & $33(80.5 \%)$ & $8(19.5 \%)$ & $7.8 \pm 1.34$ & $17.2 \pm 15.0$ \\
\hline $\mathrm{CT}$ & $6.5 \pm 1.2$ & $2(33.3 \%)$ & $4(66.6 \%)$ & $4(66.7 \%)$ & $2(33.3 \%)$ & $7.3 \pm 1.1$ & $10.1 \pm 7.5$ \\
\hline $\mathrm{CC}$ & $6.6 \pm 1.1$ & $1(33.3 \%)$ & $2(66.6 \%)$ & $2(66.7 \%)$ & $1(33.3 \%)$ & $6.5 \pm 1.05$ & $18.3 \pm 16.5$ \\
\hline$P$ value & 0.737 & \multicolumn{2}{|c|}{0.469} & \multicolumn{2}{|c|}{0.663} & 0.259 & 0.620 \\
\hline \multicolumn{8}{|c|}{$\underline{\text { rs } 4895441}$} \\
\hline AA & $6.7 \pm 1.4$ & $22(78.6 \%)$ & $6(21.4 \%)$ & $21(75.0 \%)$ & $7(25.0 \%)$ & $7.4 \pm 0.96$ & $17.8 \pm 14.9$ \\
\hline AG & $6.5 \pm 1.3$ & $14(70 \%)$ & $6(30 \%)$ & $17(85.0 \%)$ & $3(15.0 \%)$ & $8.05 \pm 1.7$ & $14.3 \pm 13.4$ \\
\hline GG & $7.0 \pm 1.4$ & $1(50 \%)$ & $1(50 \%)$ & $1(50.0 \%)$ & $1(50.0 \%)$ & $7.09 \pm 0.57$ & $17.5 \pm 23.3$ \\
\hline P Value & 0.848 & \multicolumn{2}{|c|}{0.095} & \multicolumn{2}{|c|}{0.442} & 0.278 & 0.678 \\
\hline
\end{tabular}

SD: standard deviation, P: p-value for comparing between the studied groups, $\mathrm{Hb}$ : hemoglobin.

Table 5. Relation of HBS1L-MYB (rs 9376090 and rs 4895441) genotypes with clinical and laboratory features of sickle cell disease patients.

\begin{tabular}{ccccc}
\hline Parameters & $\begin{array}{c}\text { Age of presentation } \\
\text { “months" } \\
\text { mean } \pm \text { SD }\end{array}$ & $\begin{array}{c}\text { number of crisis/year } \\
\text { mean } \pm \text { SD }\end{array}$ & $\begin{array}{c}\text { HB F\% } \\
\text { mean } \pm \text { SD }\end{array}$ & $\begin{array}{c}\text { HB S\% } \\
\text { mean } \pm \text { SD }\end{array}$ \\
\hline TT & $21.6 \pm 18$ & $\frac{\text { rs } 9376090}{3.6 \pm 1.9}$ & $8.4 \pm 6.5$ & $68.3 \pm 18.4$ \\
CT & $16.8 \pm 12$ & $2.7 \pm 1.03$ & $7.1 \pm 5.6$ & $54.4 \pm 22.6$ \\
CC & 36 & 2.0 & 1.5 & 47.0 \\
P value & 0.35 & $0.03 *$ & 0.583 & $0.031^{*}$ \\
AA & $21.6 \pm 13$ & $\underline{\text { rs } 4895441}$ & & \\
AG & $32.4 \pm 19$ & $4.1 \pm 2.2$ & $4.7 \pm 5.0$ & $63.7 \pm 24.8$ \\
P value & $0.02 *$ & $1.8 \pm 0.98$ & $9.4 \pm 6.04$ & $47.8 \pm 23.4$ \\
\hline
\end{tabular}

SD: standard deviation. p: p-value for comparing between the studied group, $\mathrm{Hb}$ : hemoglobin.

General genetic $\mathrm{HbF}$ modifiers influence disease outcomes such as frequency of painful episodes, the incidence of end-organ complications, the efficacy of hydroxyurea therapy, and life expectancy [16]. Polymorphisms in the intergenic region between HBS1L and MYB are identified as HBS1L-MYB Intergenic Polymorphism (HMIP) is significantly related to variability in expression of $\mathrm{Hb} F$ The stimulation of $\mathrm{Hb} \mathrm{F}$ expression can offer alternate treatment for the improvement of these diseases severity [17]. 
This research investigated HBS1L-MYB (rs 4895441 \& rs 9376090) gene polymorphisms in Egyptian patients with hemoglobinopathy (Beta thalassemia major \& sickle cell disease) and its relation to $\mathrm{Hb} F$ and severity of the disease.

In $\beta$-thalassemia major, age of disease presentation was (6 - 11 months), $74 \%$ of patients were on regular blood transfusion every 3 weeks and $26 \%$ every 5 weeks. These results were in agreement with Tubman et al. [18] who reported that $\beta$-thalassemia major patients remain asymptomatic until 3 - 6 months of age or more when $\mathrm{Hb} F$ production falls and adequate $\mathrm{Hb} \mathrm{A}$ can't be produced. According to blood transfusion, Langhi et al. [19] indicated that $\beta$-thalassemia major patients received regular blood transfusion throughout life, usually administered every 2 - 5 weeks depending on the transfusion needs of each individual. While in SCD patients' age of disease presentation was (9 - 36 months) and the number of crises was ( 1 - 8/year). Strouse, [20] reported that SCD patients during the first 6 months of life are protected by elevated levels of $\mathrm{Hb} \mathrm{F}$ and when reduced symptoms of SCD appear and clarified that the frequency of crises is extremely variable as crises have many triggers as hypoxemia, dehydration \& change in body temperature. In $\beta$-thalassemia major, the serum ferritin level was significantly high. Taher and Saliba [21] explained this increase in transfusion-dependent thalassemia patients by the process of iron loading secondary to transfusion therapy and in non-transfusion-dependent thalassemia patients by ineffective erythropoiesis, enhanced intestinal absorption, and hepcidin suppression.

In SCD, AG genotype \& G allele of HBS1L-MYB (rs4895441) were significantly higher than controls. Also, AG genotype was significantly associated with higher age of disease presentation, lower number of crises, higher $\mathrm{Hb} \mathrm{F}$, and lower Hb S level. These results were in agreement with Cardoso et al. [11] who demonstrated a significant association between AG genotype in African SCD patients and higher $\mathrm{Hb} F$ level, better clinical picture, and lower incidence of pain. Also, Menzel et al. [22] reported that polymorphisms in HBS1L-MYB (rs4895441) explained $9.2 \%$ of the variation in $\mathrm{Hb} F$ present in sickle cell disease patients.

No significant difference was observed between $\beta$-thalassemia major patients and controls regarding HBS1L-MYB (rs4895441) gene polymorphism and allele frequency and no association was detected between gene and disease severity (age of disease presentation, frequency of blood transfusion, splenectomy and $\mathrm{Hb}$ F). This agreed with Nguyen et al. [23] who explained that the high level of ineffective erythropoiesis observed in beta-thalassemia major could mask or inactivate the biological expression of HBS1L-MYB polymorphisms, another explanation that the levels of multiple cytokines and/or chemokines are much higher in beta-thalassemia patients than normal subjects, these small molecular weight substances in peripheral blood are likely to exert diverse effects on erythropoiesis including globin gene expression. On the contrary, Cyrus et al. [17] reported a significant association between beta-thalassemia major and HBS1L-MYB (rs 4895441 and rs 9376090) genetic polymorphism in Saudi Arabian patients. This difference may be due to marked heterogeneity in the preva- 
lence of the HBS1L-MYB allele among ethnic groups. In SCD, CT genotype \& C allele of HBS1L-MYB (rs 9376090) were significantly higher when compared to other groups. Also, CT genotype was significantly associated with a lower number of crises \& lower Hb S levels. Sales et al. [24] reported a significant impact of HBS1L-MYB (rs 9376090) polymorphism on sickle cell disease phenotype and the minor allele of HBS1L-MYB (rs 9376090) was associated with decreasing the odds of having a stroke by 3.7 folds. On the contrary, Wonkam et al. [25] reported a non-significant association between sickle cell disease severity and HBS1L-MYB (rs9376090) polymorphism. This difference may be due to marked heterogeneity in the prevalence of the HBS1L-MYB allele among ethnic groups. No significant difference was detected between $\beta$-thalassemia major patients and controls regarding HBS1L-MYB (rs 9376090) gene polymorphism and allele frequency and no significant association was detected between gene polymorphism and age of disease presentation, frequency of blood transfusion, splenectomy, $\mathrm{Hb}$ level, the severity of disease nor $\mathrm{Hb}$ F. This result was in agreement with Yunyan et al. [26], while Cyrus et al. [17] reported a significant difference in HBS1L-MYB (rs9376090) genotyping between $\beta$-thalassemia major patients and controls.

\section{Conclusion}

Lastly, we concluded that the severity of certain genetic disorders could be controlled by the expression of many genes that could decrease disease severity. In SCD, genotypes and alleles distribution of HBS1L-MYB (rs4895441\&rs9376090) were associated with lower sickling crises numbers, higher $\mathrm{Hb} \mathrm{F}$, and lower $\mathrm{Hb}$ S. So this finding supports the development of innovative therapeutic targets.

\section{Recommendations}

Other studies including a large sample size and more HBS1L-MYB gene SNPs to obtain more conclusive results about the distribution of the HBS1L-MYB gene in Egyptian patients with hemoglobinopathy are recommended.

\section{Acknowledgements}

Authors wish to acknowledge the clinical pathology lab in the Faculty of Medicine, Menoufia University for using the facilities of the PCR unit to perform this research. As well as the authors would like to express their gratitude toward all patients who participated in the study.

\section{Funding Sources}

This study was self-funded from the authors and supported by the Faculty of Medicine Menoufia University facilities.

\section{Conflicts of Interest}

The authors declare no conflicts of interest regarding the publication of this paper. 


\section{References}

[1] Kohne, E. (2011) Hemoglobinopathies: Clinical Manifestations, Diagnosis, and Treatment. Deutsches Ärzteblatt International, 108, 532-540. https://doi.org/10.3238/arztebl.2011.0532

[2] Needs, T., Gonzalez-Mosquera, L.F. and Lynch, D.T. (2020) Beta Thalassemia. StatPearls. https://www.ncbi.nlm.nih.gov/books/\%20BK531481/

[3] Mokhtar, G., Tantawy, A., Adly, A. and Ismail, E. (2011) Clinicopathological and Radiological Study of Egyptian $\beta$-Thalassemia Intermedia and $\beta$-Thalassemia Major Patients: Relation to Complications and Response to Therapy. Hemoglobin, 35, 382-405. https://doi.org/10.3109/03630269.2011.598985

[4] Elalfy, M., Farid, M., Labib, J. and RezkAllah, H. (2014) Quality of Life of Egyptian b-Thalassemia Major Children and Adolescents. Egyptian Journal of Haematology, 39, 222-226. https://doi.org/10.4103/1110-1067.153963

[5] Lim, W.F., Muniandi, L., George, E., Sathar, J., The, L.K. and Lai, M.I. (2015) HbF in $\mathrm{HbE} / \beta$-Thalassemia: A Clinical and Laboratory Correlation. Hematology Journal, 20, 349-353. https://doi.org/10.1179/1607845414y.0000000203

[6] Alenazy, G.H., Almutairi, A., AlQnazi, L., Alkharaz, G.H., Alotaibi, M., et al. (2018) Evaluation of the Most Common Complications of Sickle Cell Anemia and Management in Children: Simple Literature Review. The Egyptian Journal of Hospital Medicine, 72, 3951-3960.

[7] Inusa, B., Hsu, L., Kohli, N., Patel, A., Atoyebi, W., et al. (2019) Sickle Cell Disease: Genetics, Pathophysiology, Clinical Presentation \& Treatment. International Journal of Neonatal Screening, 5, 20. https://doi.org/10.3390/ijns5020020

[8] Bhatnagar, P., Chaturvedi, Sh., Steinberg, M., Casella, E. and Arking, D. (2017) Genome-Wide Association Study to Identify Variants Associated with Acute Severe Vaso-Occlusive Pain in Sickle Cell Anemia. The American Society of Hematology, 130, 686-688.

[9] Lai, Y.L., Chen, Y., Chen, B.Y., Zheng, H.Y., Yi, S., Li, G.J., Wei, H.W., He, S. and Zheng, C.G. (2016) Genetic Variants at BCL11A and HBS1L-MYB Loci Influence $\mathrm{Hb} \mathrm{F}$ Levels in Chinese Zhuang $\beta$-Thalassemia Intermedia Patients. Hemoglobin, 40, 405-410. https://doi.org/10.1080/03630269.2016.1253586

[10] Upadhye, D., Jain, D., Trivedi, Y., Nadkarni, A., Ghosh, K. and Colah R. (2016) Influence of Single Nucleotide Polymorphisms in the BCL11A and HBS1L-MYB Gene on the Hb F Levels and Clinical Severity of Sickle Cell Anaemia Patients. Annals of Hematology, 95, 1201-1203. https://doi.org/10.1007/s00277-016-2675-1

[11] Cardoso, G., Diniz, I., Cunha, D., Junior, J., Guerreiro, J., et al. (2014) DNA Polymorphisms at BCL11A, HBS1L-MYB and Xmn1-HBG2 Site Loci Associated with Fetal Hemoglobin Levels in Sickle Cell Anemia Patients from Northen Brazil. Blood Cells Molecules and Diseases, 53, 176-179. https://doi.org/10.1016/j.bcmd.2014.07.006

[12] Pavlova, N., Pavlov, A., Kozyavkin, S. and Slesarev, A. (2004) Recent Developments in the Optimization of Thermostable DNA Polymerases for Efficient Applications. Trends in Biotechnology, 22, 253-260. https://doi.org/10.1016/j.tibtech.2004.02.011

[13] Bustin, S., Benes, V., Garson, J., Hellemans, J., Kubista, M., et al. (2009) The MIQE Guidelines: Minimum Information for Publication of Quantitative Real-Time PCR Experiments. Clinical Chemistry, 55, 611-622. https://doi.org/10.1373/clinchem.2008.112797

[14] Steinberg, M.H. (2009) Genetic Etiologies for Phenotypic Diversity in Sickle Cell 
Anemia. The Scientific World Journal, 9, Article ID: 530852.

https://doi.org/10.1100/tsw.2009.10

[15] Galanello, R. and Origa, R. (2010) Beta-Thalassemia. Orphanet Journal of Rare Diseases, 5, 11. https://doi.org/10.1186/1750-1172-5-11

[16] Mikobi, T.M., Lukusa, T.P., Aloni, M.N., Lumaka, A.Z., Kaba, D.K., et al. (2018) Protective BCL11A and HBS1L-MYB Polymorphisms in a Cohort of 102 Congolese Patients Suffering from Sickle Cell Anemia. Journal of Clinical Laboratory, 32, e22207. https://doi.org/10.1002/jcla.22207

[17] Cyrus, C., Vatte, C., Borgio, J.F., Al-Rubaish, A., Chathoth, S., et al. (2017) Existence of HbF Enhancer Haplotypes at HBS1L-MYB Intergenic Region in Transfusion-Dependent Saudi $\beta$-Thalassemia Patients. BioMed Research International, 2017, Article ID: 1972429. https://doi.org/10.1155/2017/1972429

[18] Tubman, V.N., Fung, E.B., Vogiatzi, M., Thompson, A.A., Rogers, Z.R., et al. (2015) Guidelines for the Standard Monitoring of Patients with Thalassemia: Report of the Thalassemia Longitudinal Cohort. Journal of Pediatric Hematology/Oncology, 37, e162-e169. https://doi.org/10.1097/MPH.0000000000000307

[19] Langhi, D., Ubiali, E., Marques, J., Loggetto, S., Silvinato, A., et al. (2016) Guidelines on Beta-Thalassemia Major-Regular Blood Transfusion Therapy. Brazilian Association of Hematology, 38, 341-345. https://doi.org/10.1016/j.bjhh.2016.09.003

[20] Strouse, J. (2016) Sickle Cell Disease. In: Aminoff, M.J., Boller, F. and Swaab, D.F., Eds., Handbook of Clinical Neurology, Vol. 138, Elsevier B.V., Amsterdam, 311-324.

[21] Taher, A. and Saliba, A. (2017) Iron Overload in Thalassemia: Different Organs at Different Rates. Hematology. American Society of Hematological Education Program, 2017, 265-271. https://doi.org/10.1182/asheducation-2017.1.265

[22] Menzel, S. and Thein, S. (2019) Genetic Modifiers of Fetal Haemoglobin in Sickle Cell Disease. Molecular Diagnosis \& Therapy, 23, 235-244.

https://doi.org/10.1007/s40291-018-0370-8

[23] Nguyen, T.K.T., Joly, P., Bardel, C., Moulsma, M., Francina, A., et al. (2010) The $\mathrm{XmnI}^{\mathrm{G}}$ Gamma Polymorphism Influences Hemoglobin F Synthesis Contrary to BCL11A and HBS1L-MYB SNPs in Cohort of 57 Beta-Thalassemia Intermedia Patients. Blood Cells, Molecules, and Diseases, 45, 124-127. https://doi.org/10.1016/j.bcmd.2010.04.002

[24] Sales, R.R., Belisário, A.R., Faria, G., Mendes, F., Luizon, M.R., et al. (2020) Functional Polymorphisms of BCL11A and HBS1L-MYB Genes Affect Both Fetal Hemoglobin Level and Clinical Outcomes in a Cohort of Children with Sickle Cell Anemia. Annals of Hematology, 99, 1453-1463. https://doi.org/10.1007/s00277-020-04079-2

[25] Wonkam, A., Mnika, K., Bitoungui, V., Chemegni, B., Kengne, A., et al. (2018) Clinical and Genetic Factors Are Associated with Pain and Hospitalization Rates in Sickle Cell Anaemia in Cameroon. British Journal of Haematology, 180, 134-146. https://doi.org/10.1111/bjh.15011

[26] He, Y.Y., Lin, W.X. and Luo, J.M. (2011) Influences of Genetic Variation on Fetal Hemoglobin. Pediatric Hematology and Oncology, 28, 708-717.

https://doi.org/10.3109/08880018.2011.616573 